\title{
POTENTIAL OF OPEN DATA IN THE CZECH REPUBLIC
}

\author{
Jan Boubín
}

\begin{abstract}
The paper Potential of open data in the Czech Republic deals with the current situation of open data government and autonomous institutions in the Czech Republic in comparison with other European Union countries (Great Britain, France, Belgium, Austria, Estonia, ...) and defines the possibilities of open data economic development of the Czech Republic. Methodology of the paper includes a search resources dealing with the issue of open data in the Czech Republic and the European Union, comparing the obtained data, the analysis of obtained data and draft of recommendations for further development. The first part is an evaluation of the current situation and the situation compared with other EU countries. Further conditions for further development and evaluation of the potential of open data for the Czech Republic. The final section of the paper deals with evaluation of possibilities open application data management processes of companies in the Czech Republic in terms of strategic and innovation management. The result is an overview of the potential use of open data in the context of economic development and an estimate of the trend in applications open at the government level.
\end{abstract}

\section{Key words}

Czech Republic, economic and innovation potential, economic development, European Union, government data, open data

The paper was written within the project of Student Grant Competition at the Technical University of Liberec no. 3600/21138 „Actual application of open data in the Czech Republic” in 2016.

\section{Introduction and theoretical basis - Open Data}

Open data represents information, data and values which are freely available for using by anyone. The main parameters include free access, data structuring and clarity, machine readable treatment and availability without technical obstacles. Their format allows easy orientation and searching data needed for every single users. (MV, 2015; Open Definition, 2014)

Open data conceal significant potential for the development of the economic environment of the country. (Boček, 2012b) Open data provided by private companies or by government can lead to build an optimal business strategy, changes in strategy or finding new business activities and opportunities. (Saebi, 2015) With the closely related large influence on the innovation potential of companies which can consider suitability of innovation by using open data. Then it is possible to adequately manage and plan this innovation too. (Lathrop, 2010; Open Knowledge Foundation, 2012)

All of the above written application options of open data lead to reducing costs and help to intensive economic growth. From the perspective of government, open data represents 
indirect support for the economic efficiency of the state and elimination of the risks of market failure. (Pollock, 2012) Concurrently, open data serves as a tool for increasing transparency and reducing corruption in individual countries. (Open Knowledge International, 2016b; Solom, 2012)

\section{Methodology}

The main research question of the paper is: What is the current level of application of open data by government and local government institutions in the Czech republic and how is the potential development of open data in the Czech republic?

The paper has a descriptive character. The paper represent a description of the current situation of the application of open government data in the Czech republic by international recognized quantifiers and finding opportunities for further development.

Methodology of the paper includes a literature review dealing with the issue of open government data in the Czech republic and the European Union, comparison of obtained data, the analysis of information learned and draft of recommendations for the future development of open data in the Czech republic.

\section{Results Open Data Index and Open Data Barometer}

For comparing the level of application of open data in the Czech republic and countries of the European Union are used an internationally recognized quantifiers - Open Data Index and Open Data Barometer which are published annually by the Open Knowledge International and by the World Wide Web Foundation, both since 2013. (Open Data Barometer, 2016a; Open Knowledge International, 2016a)

Open Data Index examines the level of application of various forms of open government data like government budget, national statistics, water quality or land ownership (all categories in Table 1). Open Knowledge International comprehensively evaluated the quality of open datasets in percentage. Specific data of the percentage data evaluation and order of the world ranking are shown in Table 1. (Open Knowledge International, 2016a) 


\begin{tabular}{l|c|c|c|c|c|c}
\hline \multirow{2}{*}{} & \multicolumn{2}{|c|}{$\mathbf{2 0 1 3}$} & \multicolumn{2}{c|}{$\mathbf{2 0 1 4}$} & \multicolumn{2}{c}{2015} \\
\cline { 2 - 7 } & Score & Rank & Score & Rank & Score & Rank \\
\hline National Statistics & $80 \%$ & 12. & $90 \%$ & 16. & $100 \%$ & 1. \\
\hline Government Budget & $45 \%$ & 36. & $70 \%$ & 22. & $100 \%$ & 1. \\
\hline Legislation & $45 \%$ & 26. & $45 \%$ & 33. & $60 \%$ & 27. \\
\hline Procurement tenders & - & - & - & - & $60 \%$ & 26. \\
\hline National Map & $100 \%$ & 1. & $100 \%$ & 1. & $100 \%$ & 1. \\
\hline Weather forecast & $30 \%$ & 44. & $100 \%$ & 1. & $45 \%$ & 35. \\
\hline Pollutant Emissions & - & - & - & - & $10 \%$ & 77. \\
\hline Company Register & $35 \%$ & 35. & $35 \%$ & 51. & $45 \%$ & 30. \\
\hline Location datasets & $50 \%$ & 13. & $90 \%$ & 5. & $15 \%$ & 58. \\
\hline Water quality & $20 \%$ & 41. & $70 \%$ & 10. & $70 \%$ & 14. \\
\hline Land Ownership & - & - & - & - & $10 \%$ & 46. \\
\hline Government Spending & $0 \%$ & 40. & $10 \%$ & 15. & $10 \%$ & 8. \\
\hline Transport Timetables & $45 \%$ & 13. & $45 \%$ & 24. & - & - \\
\hline Total & $45 \%$ & 29. & $66 \%$ & 13. & $52 \%$ & 21. \\
\hline
\end{tabular}

Table 1: Open Data Index

Czech republic showed efforts to improve the quality of open data in 2014 when was recorded the percentage growth in eight out of the ten followed datasets. That meant a rise in the total percentage rating of 21 percentage points and a significant shift in the national rankings to $13^{\text {th }}$ place. In 2015, the government of the Czech republic focused on the development of the publication of government data and national statistics. However, in other sections there has been a stagnation or decline (especially in the company register section) of percentage rating. Czech republic recorded a percentage positional fall which was caused by evaluation of new datasets in which the Czech republic has a significant weaknesses (mainly in sections of water quality and weather forecasts - important figures for agriculture). (Open Knowledge International, 2016a)

Open Data Barometer comprehensively evaluate the application of open government data in 92 countries based on three basic sections - readiness, implementation and impact. Open Data Barometer published averages of countries in Europe and Central Asia which includes the Czech republic. (Open Data Barometer, 2016b)

In each of the sections Open Data Barometer attach a numeric value, the maximum is 100 points and the minimum is 0 points. In essence, that is the percentage appreciation "mastery” of the issue. (Open Data Barometer, 2016a)

Readiness section includes four main subsections - government policy, government action, citizens and civil rights and entrepreneurs and business. Between 2013 and 2014 the Czech republic recorded a slight increase of two percentage points. But in 2015 there was a fall of 
5 points. The most important position of the Czech republic is in the section of citizens and civil rights which amounts to 83 points. Annual increase was 22 points. Czech republic is above the European average as well as in government policy. Conversely, the Czech republic lags in the section of government action (severe loss of 14 points) and in the section of entrepreneurs and business in comparison with European average. The data are reported in Table 2. (Open Data Barometer, 2016c)

\begin{tabular}{l|c|c|c|c|c|c}
\hline & \multicolumn{3}{|c|}{ Czech republic } & \multicolumn{3}{c}{ Europe and Central Asia } \\
\cline { 2 - 7 } & $\mathbf{2 0 1 3}$ & $\mathbf{2 0 1 4}$ & $\mathbf{2 0 1 5}$ & $\mathbf{2 0 1 3}$ & $\mathbf{2 0 1 4}$ & $\mathbf{2 0 1 5}$ \\
\hline Government Policies & 43 & 44 & 56 & 64 & 68 & 36 \\
\hline Government Action & 83 & 87 & 49 & 74 & 79 & 63 \\
\hline Citizens and civil rights & 61 & 61 & 83 & 62 & 70 & 79 \\
\hline Entrepreneurs and business & 36 & 58 & 56 & 54 & 54 & 64 \\
\hline
\end{tabular}

Table 2: Open Data Barometer of Readiness

On data about readiness is evident good basis for a stable political and legislative situation including the positive development in the last three years. The business environment in the Czech republic is not compared to other countries in Europe and Central Asia assessed positively. Although between 2013 and 2014 there was a significant improvement, the situation continues to Czech republic is less than the average. In 2015 there was a big criticism of government actions and a slump in the value of index of almost 40 points. Despite the stable political situation, a series of government interventions can't be evaluated positively. (Open Data Barometer, 2016c)

The implementation involves three basic types of datasets - innovation cluster, social policy cluster and accountability cluster. Accountability cluster has a steady growth in the Czech republic. This increases transparency of the policy which has a positive impact on reducing corruption. In this type of datasets the Czech republic rather significantly above the average for Europe and Central Asia. Unfortunately, there is the opposite situation in the remaining datasets. The innovation cluster occurred a permanent reduction of the index in the last three years. The reasons may be two - weak innovation support from the government or the desire to protect information through copyright and information isn't shared in the form of open data. It wasn't evaluated positively a big drop of social policy index in 2015. This wasn't sufficiently opened and data in this sector are still below the European average. Specific figures are shown in Table 3. (Open Data Barometer, 2016c) 


\begin{tabular}{l|c|c|c|c|c|c}
\hline \multirow{2}{*}{} & \multicolumn{3}{|c|}{ Czech republic } & \multicolumn{3}{c}{ Europe and Central Asia } \\
\cline { 2 - 7 } & $\mathbf{2 0 1 3}$ & $\mathbf{2 0 1 4}$ & $\mathbf{2 0 1 5}$ & $\mathbf{2 0 1 3}$ & $\mathbf{2 0 1 4}$ & $\mathbf{2 0 1 5}$ \\
\hline Innovation Cluster & 57 & 53 & 47 & 52 & 54 & 54 \\
\hline Social Policy Cluster & 27 & 65 & 33 & 42 & 44 & 58 \\
\hline Accountability Cluster & 36 & 52 & 52 & 39 & 50 & 39 \\
\hline
\end{tabular}

Table 3: Open Data Barometer of Implementation

The impact sector covers political impact, social impact and economic impact. In the Czech republic there is a very positive political impact primarily when the Czech republic index exceeds the European average of 19 points, as can be seen in Table 4 . Above all, political impact increased annual by 34 points in 2015 . Social impact in all three years oscillated around the European average. It is evident that the Czech republic is comparable with neighboring countries in this sector. For positive can be considered economic impact that exceeds the European average of 20 points in the Czech republic. From an economic perspective, opening data is beneficial for the Czech republic and delivers economic returns. (Open Data Barometer, 2016c)

\begin{tabular}{l|c|c|c|c|c|c}
\hline & \multicolumn{3}{|c|}{ Czech republic } & \multicolumn{3}{c}{ Europe and Central Asia } \\
\cline { 2 - 7 } & $\mathbf{2 0 1 3}$ & $\mathbf{2 0 1 4}$ & $\mathbf{2 0 1 5}$ & $\mathbf{2 0 1 3}$ & $\mathbf{2 0 1 4}$ & $\mathbf{2 0 1 5}$ \\
\hline Political Impact & 24 & 26 & 60 & 18 & 29 & 41 \\
\hline Social Impact & 39 & 39 & 29 & 39 & 44 & 27 \\
\hline Economic Impact & - & - & 56 & - & - & 36 \\
\hline
\end{tabular}

Table 4: Open Data Barometer of Impact 
Interestingly looks development of open data application from an overall perspective. In 2013 included the Czech republic $22^{\text {nd }}$ in the world ranking which represented the $12^{\text {th }}$ place among the 17 European Union countries (no every countries are in the Open Data Barometer) with an index of 43.18 points. European Union average stood at 52.69 points. In 2014 Czech republic advanced to the $17^{\text {th }}$ place in the world and the $10^{\text {th }}$ in the European Union (this year there were 18 countries in the database). Index of the Czech republic was 58.7 points, improving therefore amounted more than 15 points. In the European Union also increased index but only by about 7.5 points to 60.11 points. In 2015 the index declined in the European Union by more than three points to 57.72 points. But Czech republic recorded a drop of 9 points at 49.15 points. The slump that followed in the overall standings on $26^{\text {th }}$ place in the world and $13^{\text {th }}$ place out of 19 participating countries from the European Union. Table 5 shows the development of the countries of the European Union in the years 2013-2015. (Open Data Barometer, 2016b)

\begin{tabular}{l|c|c|c|l|c|c|c}
\hline & $\mathbf{2 0 1 3}$ & $\mathbf{2 0 1 4}$ & $\mathbf{2 0 1 5}$ & & $\mathbf{2 0 1 3}$ & $\mathbf{2 0 1 4}$ & $\mathbf{2 0 1 5}$ \\
\hline Great Britain & 100 & 100 & 100 & Belgium & 34,8 & 47,29 & 52,62 \\
\hline France & 63,92 & 80,21 & 81,65 & Estonia & 49,45 & 60,18 & 50,63 \\
\hline Denmark & 71,78 & 70,13 & 76,62 & $\begin{array}{l}\text { Czech } \\
\text { republic }\end{array}$ & 43,18 & 58,7 & 49,15 \\
\hline Netherlands & 63,66 & 75,79 & 75,13 & Ireland & 35,76 & 40,74 & 46,53 \\
\hline Sweden & 85,75 & 83,7 & 69,26 & Portugal & 38,63 & 46,12 & 41,38 \\
\hline Finland & 49,44 & 66,49 & 65,45 & Poland & - & 36,99 & 39,95 \\
\hline Germany & 65,1 & 67,63 & 64,79 & Greece & 27,59 & 40,79 & 38,48 \\
\hline Spain & 48,19 & 59,89 & 64,35 & Slovakia & - & - & 37,16 \\
\hline Austria & 46,3 & 58,52 & 64,18 & Hungary & 26,9 & 38,26 & 25,54 \\
\hline Italy & 45,3 & 50,58 & 53,78 & & & & \\
\hline
\end{tabular}

Table 5: Overall Open Data Barometer score for European Unio countries

\section{Discussion and conclusions}

Open data is a modern economic tool. They represent the future for the public and private sectors. Regardless they are still often neglected in the Czech Republic and their significance is still slightly underestimated. Great development experience open data across Europe, particularly in Great Britain. Yet the current range of information about open data is not sufficient in the Czech republic. (Boček, 2012a; Saebi, 2015; Solom, 2012)

In 2011 the Czech republic commit to open their data, on the basis of an agreement Open Government Partnership. But the opening of the data significantly extends and the Czech republic still fails to meet its obligations. It is important to increase efforts by the government of Czech republic and streamline the process of opening data.

There is evident lack of the experience and awareness of open data in the Czech republic. If-the responsible organizations received detailed information about open data benefits and 
possibilities, it could lead to an increase in entities that would use an open data. This is related to the expected faster growth of the economy.

It can be assumed that the development of open data will be complicated without information support of head institutions of Czech republic government. Companies and organizations still do not see the open data benefits. Open data bring benefits in a wide range of planning and management of corporate or institutional activities according to economic experts opinion. However these benefits are open data often neglected or these benefits institutions and companies do not know. Because of this fact the importance of greater information support of open data with emphasis on the positive impact on the development of the market and the institutions themselves.

Generally it can be difficult to predict the future development of the application of open data in the Czech republic because there are data from only three years. The positive economic impact is a motivation for opening data but the fall in evaluating the application of open data in 2015 was quite substantial. The Czech government has big gaps particularly in the evaluation of its activities which is necessary to change for better overall economic situation of the state, not only for open data situation. Likewise, there should be greater support for the business environment. Although the legislative environment is assessed positively in the Czech republic, some laws for entrepreneurs represent a „brake“ for their development potential. Likewise, support for opening data is not on adequate level.

Political, social and economic impact should be a motivation for opening data. All these sections have a positive effect on the economic situation in the country, as well as to improve the business environment, reducing corruption and increasing the transparency of government institutions and private companies.

Open data is at the beginning of its development in the Czech republic and their application is not sufficiently high. Lacks significant support on the part of the Czech republic and the European Union. Overall the open data should promote across all institutions for effective economic growth and for increasing the transparency. For the same reason there should be support for opening data in organizations of public sector and legislative support for opening data.

The power of open data is in the range of applicability. Data can be used practically in all parts of planning and management of companies and institutions. Can be expected a wider range of data use, not only in the Czech republic. The reasons are mainly significant return of investment in the form of savings (minimization "unnecessary" costs) or in the form of increasing profits. Besides the positive economic impacts the open data contributes to increasing transparency which is also closely related to the elimination of corrupt practises in individual countries. Generally, open data have a positive economic and social impact. Therefore it is necessary to support opening data and to foster economic growth by this way. 


\section{Bibliography}

Boček, Jan, Jakub Mráček a Jindřich Mynarz, 2012a. Otevřená data: Př́ležitost pro Českou republiku. In: Nadace Open Society Fund [online]. Praha: Nadace Open Society Fund Praha [online]. Praha: Nadace Open Society Fund. 2012 [cit. 18. 5. 2016]. Available from: http://www.otevrenadata.cz/.

Boček, Jan , 2012b. Otevřená data ve státní správě: Nová éra rozhodování. In: Nadace Open Society Fund [online]. Praha: Nadace Open Society Fund Praha a Otevřená společnost, o.p.s. 2012. [cit.18. 5. 2016]. Available from: http://www.osf.cz/wp-content/uploads/2015/08/ODSS_Text_web_01.pdf

Lathrop, Daniel a Laurel Ruma, 2010. Open Government: Collaboration, Transparency, and Participation in Practice. Newton: O'Reilly Media, 432 pages. ISBN 978-0-596-80435-0.

MV, 2015. Otevřená data. In: Ministerstvo vnitra České republiky [online]. Praha: Ministerstvo vnitra České republiky. 2015 [cit. 14. 6. 2016]. Available from: http://www.mvcr.cz/clanek/otevrena-data. aspx.

Open Data Barometer, 2016a. Research Method. In: Open Data Barometer [online]. Washington: World Wide Web Foundation. 2016 [cit. 2. 6. 2016]. Available from: http://opendatabarometer. org/3rdEdition/methodology/

Open Data Barometer, 2016b. Ranking Open Data Barometer. In: Open Data Barometer [online]. Washington: World Wide Web Foundation. 2016 [cit. 12. 6. 2016]. Available from: http:// opendatabarometer.org/data-explorer/?_year=2015\&indicator=ODB\&lang=en

Open Data Barometer, 2016c. Czech republic. In: Open Data Barometer [online]. Washington: World Wide Web Foundation. 2016 [cit. 19. 6. 2016]. Available from: http://opendatabarometer.org/ data-explorer/?_year=2015\&indicator=ODB\&lang=en\&open=CZE

Open Definition, 2014. Open Definition: Version 1.1. In: Open Definion [online]. Cambridge: Open Knowledge Foundation. 2014 [cit. 29. 5. 2016]. Available from: http://opendefinition.org/.

Open Knowledge Foundation, 2012. Open Data Handbook. In: Open Knowledge Foundation [online]. Cambridge: Open Knowledge Foundation. 2012. [cit. 3. 6. 2016].

Available from: http://opendatahandbook.org/en/.

Open Knowledge International, 2016. Vision and Values. In: Open Knowledge International [online]. United Kingdom: Open Knowledge International. 2012. [cit. 23. 6. 2016]. Available from: https:// okfn.org/about/vision-and-values/

Pollock, Rufus, 2012. Opening up meeting In: Open Knowledge Foundation \& Open Data. [online]. Cambridge: Open Knowledge Foundation. 2012 [cit. 21. 6. 2016]. Available from: http://www. slideshare.net/OpeningUp/open-data-conference-rufus-pollock Saebi, Tina a Nicolai J. Foss, 2015. Business models for open innovation: Matching heterogeneous open innovation strategies with business model dimensions. European Management Journal. The Nietherlands: Elsevier, 33(3), pages 201-213. ISSN 0263-2373.

Solom, David J. a Bo.Christer Björk, 2012. A Study of Open Access Journals Using Article Processing Charges. Journal of American Society for Information Science and Technology. United States of America: Association for Information Science and Technoligy, 63(8). ISSN 2330-1643.

Jan Boubín_ jan.boubin@tul.cz

Technical University of Liberec Faculty of Economics

Voroněžská 13, 46001 Liberec

Czech Republic 